\title{
Cursos Preparatórios para os Exames de Residência e a Evasão dos Cenários de Prática: Cadê o Interno que Estava Aqui?
}

\author{
Preparatory Courses for Residency Examinations \\ and the Avoidance of Practical Settings: Where Is \\ the Clerkship Student That Was Here?
}

\author{
Júlio César Andrél \\ Júlio César Razera de Melo ${ }^{I}$ \\ Alba Regina de Abreu LimaI \\ Sérgio Luis Aparecido Brienzel \\ Alexandre Lins Werneck ${ }^{I}$ \\ Patrícia da Silva Fucutall,III
}

\section{PALAVRAS-CHAVE \\ - Educação Superior. \\ - Educação Médica. \\ - Cursinhos Preparatórios. \\ - Internato e Residência Médica.}

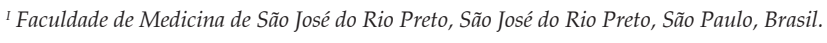

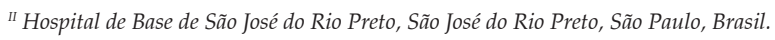

${ }^{\text {III }}$ Faculdade de Medicina FACERES, São José do Rio Preto, São Paulo, Brasil.

\begin{abstract}
Embora não seja obrigatória, a residência médica faz parte do processo de ensino e da formação dos médicos e é considerada padrão ouro na modalidade de ensino de pós-graduação lato sensu. Entretanto, o número de vagas para residência médica não acompanhou a expansão dos cursos de graduação em Medicina, gerando uma intensa disputa por uma vaga nos cursos de residência, o que fez proliferar os cursos preparatórios para os exames de residência (CP). A evasão do interno de Medicina de suas atividades acadêmicas para se dedicar às atividades dos cursinhos preparatórios para os exames de residência médica preocupa os docentes. Este estudo tem por objetivo traçar um perfil no internato da Faculdade de Medicina de São José do Rio Preto (Famerp) sobre a adesão dos internos aos CP. Os resultados apontam que a imensa maioria dos 297 alunos pesquisados pretende fazer residência médica e que apenas 27 alunos (84,4\%) dos 32 que consideravam o curso de preparação necessário, mas não dispunham de recursos financeiros para frequentá-los. Os entrevistados afirmaram que a maior qualidade dos cursos preparatórios reside na didática das aulas e que a maior desvantagem destes é a dissociação entre conteúdo teórico e prático, também vivida no internato. Concluímos que a percepção dos internos e acadêmicos de Medicina é bem definida quanto aos cursinhos preparatórios para residência médica. Apesar de aderirem à prática destes cursinhos, sabem que há uma dicotomia entre a teoria e a prática oferecida no internato, o que prejudica a formação profissional. A grande maioria dos acadêmicos pesquisados pretende fazer a residência médica após o internato, dando continuidade aos estudos e ao aprendizado. Por outro lado, a atual conjuntura do mercado de trabalho na área da medicina, marcada por uma concorrência acirrada, e as exigências constantes de atualização e aperfeiçoamento levam os acadêmicos a verem na residência o único caminho natural após o internato e ainda uma alternativa para sanar as possíveis deficiências do internato. Mudanças na graduação sugeridas pelos pesquisados, como melhor didática em aulas da graduação e a abordagem de conteúdo teórico durante o internato, refletem a deficiência da graduação e do internato, a qual pode ser sanada com uma postura mais assertiva de professores e preceptores.
\end{abstract}




\section{KEY-WORDS}

- Higher Education.

- Medical Education.

- Preparatory Courses.

- Internship and Residency.

\begin{abstract}
Although not compulsory, medical residency is part through the physicians' teaching and training process. It is considered the gold standard in the teaching modality of Lato Sensu Graduate Programs. However, the number of residency positions available has not kept pace with the expansion of medical undergraduate courses, resulting in high levels of competition for medical residency vacancies, and a proliferation of preparatory courses (PC) offering supervised postgraduate training. The evasion of clerkship students from their academic activities to take prep courses in order to apply for a residency position is a cause for concern among teachers. This study outlines a profile in the São José do Rio Preto (Famerp) School of Medicine internship programme regarding medical interns' adherence to prep courses. The results indicate that the vast majority of the study sample (297 students) intended to apply for a medical residency program. Only 27 (84.4\%) out of the 32 students, despite considering the prep course necessary, did not have the financial resources to attend these courses. The interviewees pointed out that the higher quality of prep courses is due to the didactics of the classes, but that the main disadvantage of these classes is the dissociation between the theoretical and practical content, also experienced during the internship. We conclude that the perceptions of the interns and medical students is well defined in relation to prep courses to get into a medical residency. Although they adhere to the practice of these courses, they know that there is a dichotomy between the theory and the practice that is offered in the internship, and that this hinders their professional training. The vast majority of the study sample intended to apply for the medical residency program after the internship, continuing their studies and learning. On the other hand, the current environment of the job market in the field of medicine, marked by fierce competition and constant requirements to update and improve, is leading students to view the medical residency as the only natural way to continue after the internship. They also see it as a way of making up for any shortfalls of the internship program. Changes in undergraduate courses, such as a better class didactics and the approach to theoretical content during the internship, reflect the deficiency of undergraduate courses and the internship program, but which can be remedied with a more assertive attitude on the part of teachers and preceptors.
\end{abstract}

Recebido em: 6/9/2017

Aceito em: 30/7/2018

\section{INTRODUCTION}

The training of specialists was not a priority issue, nor was it emphasized from the beginning in the design of the theoretical framework of medical education in Brazili. Only from 1945 the first medical residency programs emerge in São Paulo and Rio de Janeiro.

The National Commission of Medical Residency (NCMR) regimented the postgraduate modality as specialization courses based on in-service training for physicians being responsible for the accreditation of medical residency programs in Brazil ${ }^{4,5}$. Federal Medical Residency Law no ${ }^{\circ}$ 6.932, from June 7, 1981, defines medical residency as a modality of graduate education for doctors. It is characterized by in-service training in the form of a specialization course ${ }^{6}$. Medical update was implemented through recycling internships, self-learning through books, journal subscription, a few congresses and courses, and this were sufficient to practice medicine in a proper manner?

Even though Medical Residency is not compulsory, it is considered as part of physicians' teaching and training process. It is defined as the gold standard modality of Lato Sensu postgraduate program, as well as an essential step in defining the medical professional profile. Medical residency shapes the future professional into a specialty ${ }^{1,3}$. For newly trained physicians, medical residency combines theoretical knowledge with clinical experience acquired through professionals and medical preceptors. The professional begins to approach the patients by building the ethics of his/her professional relationship, privileging the relationship physician-patient, not the diseases ${ }^{8}$. Despite the importance of Medical Residency for the development of medical professionals and also to service delivery, it was not a concern neither a target of government 
planning. This becomes evident when analyzing government policies regarding health or education sectors ${ }^{8}$.

Since 1990s, there was a progressive increase over the number of medical schools throughout the country, mainly the private ones. This increase was combined in the presence of disqualified faculty, with little or no research activity, itinerant visiting teachers, and the lack of practice scenarios for students, with eminently theoretical courses, what led to the crisis of medical education ${ }^{8}$. On the other hand, in the 1990s, there were debates and questionings about the weaknesses of the Brazilian medical education. There was a growing dissatisfaction among the community regarding the education obtained by graduated physicians in medical schools. They seemed to be unprepared for the increasingly required new professional, social, and institutional practices ${ }^{3}$.

Up to March 2016, there were 268 medical schools in operation. The number of students graduating per year was of 24,401 . The offer of vacancies for medical residency programs did not follow the increase in numbers of medical schools and doctors graduated in Brazil. In 2016, there were available 13,795 direct access program vacancies ${ }^{9}$. This produced deficits, as well as a fierce competition in certain specialties or regions of the country ${ }^{8}$.

The Normative Resolution $n^{\circ}$ 01/99, published by the National Commission of Medical Residency, established that medical residency examinations should be composed of an objective theoretical evaluation corresponding to $90 \%$ of the final score. The remaining 10\% should be obtained through interview, curriculum evaluation and/or practical examination. This is what we called a 90/10 model $^{5}$. These factors gave rise to a growing phenomenon in the country, the preparatory courses for medical residency examinations. These are profit-seeking courses, which function in the same way of the preparatory courses for university admission that offer intensive classes ${ }^{1}$.

Prep course companies define themselves as the means of transmitting knowledge in an optimized way and able to reconcile learning with better results in medical residency examinations using various resources, such as updated teaching materials, exercise lists, pretests and extra courses to prepare the student for written tests, practice, and interview ${ }^{1}$. In addition to providing an infrastructure that includes auditoriums, and lessons via satellite, and even classes via the Internet, these courses reveal the intention to complement and systematize the medical study, in order to prepare the student for medical residency examinations.

The growth in the supply of this type of service worries medical entities and specialists, and it divides opinions in the academic environment regarding prep courses, which is controversial and the reason for lively debate. Students, who are increasingly concerned about passing the examinations, leave curricular activities in the background and enroll themselves in these courses.

Most teachers are afraid of the establishment of a vicious circle in which gaps in the medical academic background and a method of evaluation for medical residency examination, basically theoretical, lead to the student to seek prep courses in order to fill these gaps. This triad may lead eventually to further deterioration in medical background, especially in relation to development of skills, as well as in the incorporation of medical ethics, since the student is discouraged from dedicating to the clerkship ${ }^{1}$. Medical residency examinations are evaluated using the model $90 / 10$, which privileges theoretical knowledge rather than the practical knowledge. This causes the students to move away from the clinical activities of the professional practice in the clerkship and to devote themselves to the theoretical study of the content addressed in medical residency examinations to the detriment of skills and competences to be acquired for the full training of the physician $^{8}$.

New graduated physicians seek out temporary work opportunities in public primary health care services and in emergency care units until they get a vacancy in medical residency. They use to work in unsafe conditions that contribute to the precariousness of the health system. The proportion of newly graduated physicians who are unable to obtain residency that is increasing. There was an increase in physicians on duty; however, physicians who work in private practice and in the private sector decreased. These data show the appearance of a large physicians' contingent without access medical residence, which leads to a dichotomy, a kind of perverse division between qualified and unqualified physicians ${ }^{8}$.

However, the vast majority of students consider that prep courses have become part of the academic training ${ }^{1}$.

According to Chehuen Neto et al. ${ }^{10}$, at the Federal University of Juiz de Fora, about three out of four medical students attending the seventh, eight, and ninth semesters of medical school declare their intention to enroll in prep courses, aiming at updating and/or reviewing the exam content. Among those who do not intend to enroll, the main reason is the lack of financial conditions ${ }^{10}$.

The medical clerkship student avoidance of his/her academic activities to dedicate himself/herself to prep course activities in order to get ready for medical residency examination raised a double concern: the indiscriminate proliferation of prep courses, charging fees not always accessible to all 
clerkship students, further reinforcing socioeconomic inequalities, already so cruel in our society, and the questioning about the actual acquisition of the skills and competences necessary for the full training of the physician. The knowledge of this reality and seeking options to make the intern to throw himself / herself "heart and soul" to clerkship justify this study.

This study aims to outline the profile of the Faculdade de Medicina de São José do Rio Preto (Famerp) clerkship program regarding interns' adhesion to prep courses.

\section{MATERIAL AND METHODS}

This is a cross-sectional study using a quantitative and a qualitative approach that analyzes the perception of Famerp medical students about clerkship and residency through a semi-structured questionnaire composed of 27 open and closed questions. The study sample was composed of 299 first- to sixth-year medical students of both sexes, attending the undergraduate course at Famerp. The research was conducted during 2015, when the participants answered the questionnaire. A self-applicable questionnaire was prepared by the own researcher. The participants had access to an Internet link to use an electronic form sent by e-mail. This study was approved by the Ethics and Research Committee Opinion \# 1.192.829.

\section{Statistical analysis}

We used a descriptive statistical analysis. Categorical data were expressed in absolute numbers and frequency. Categorical variables between groups were tested with Pearson's Chisquare test or Fisher's exact test, when appropriate. In order to compare questions with answers on Likert scale, students were grouped into two categories: "discordant" or "concordant", excluding those who responded "indifferently". All tests were two-tailed and $\mathrm{p}$ value $<0.05$ was considered as significant. The statistical software IBM-SPSS Statistics version 24 (IBM Corporation, NY, USA), was used for all tests.

\section{RESULTS}

The study sample was composed of 299 students who answered the questionnaire and were included in the analysis. They were first- through sixth-year medical students distributed as follows: 58 (19.4\%; first-year), 63 (21\%; second-year, 36 (12\%; third-year), 56 (18.7\%; fourth-year), 31 (10.4\%; fifthyear), and 55 (18.5\%; sixth-year).

Table 1 shows the students' expectation of following medical residency, the knowledge about prep courses to get ready for medical residency examination, and how they take advantage of their time between the study to get ready for medical residency examination and clerkship activities. This question was answered only by fifth-year and sixth-year medical students.

\begin{tabular}{|c|c|c|}
\hline \multicolumn{3}{|c|}{$\begin{array}{c}\text { How is time organization between clerkship and } \\
\text { studies for medical residency examination? }\end{array}$} \\
\hline & $5^{\text {th }}$ year & $6^{\text {th }}$ year \\
\hline Balance the distribution of time & $15(51 \%)$ & $32(59 \%)$ \\
\hline Prioritize clerkship & $7(24 \%)$ & $2(4 \%)$ \\
\hline Prioritize study to take the examination & $7(24 \%)$ & $20(37 \%)$ \\
\hline Total & 29 & 54 \\
\hline
\end{tabular}

When they were asked about their expectations of following medical residency, 297 out of 299 students answered they wanted to follow medical residency. Only 2 (3\%) students, who were first-year medical students, answered they did not intend to follow medical residency.

Regarding prep courses to get ready for medical residency examination, students were initially asked whether they were aware of their existence.

Only $4(1.4 \%)$ of 298 students reported they were not aware of such courses (two first-year medical students, one second-year medical student, and one fourth-year medical student). Then, they were asked about how they become aware of these courses. Awareness of these courses to 263 (90.7\%) out of 290 respondents came from colleagues attending prep courses. The remaining 9.3\% were divided between media, advertisement of prep courses, and from relatives or teachers.

To take the prep course to study for medical residency examination: student's decision and motivations

Until the third-year of medical school, no student declared to take the prep course in order to study for medical residency examination. However, it was observed that $2 \%, 55 \%$, and $84 \%$ of the fourth-year, fifth-year, and sixth-year medical students, respectively, were taking a prep course to get ready for medical residency examination.

The question for those students, who had not taken the prep course, was: when do you wish to take the prep course to get ready for medical residency examination? Thirty-seven students stated they did not wish to take the prep course, distributed as follows: six first-year medical students; eight second-year medical students; six third-year medical students; four fourth-year medical students; four fifth-year medical students, and nine sixth-year medical students.

Regarding those who answered positively to the question, none of them stated they would take the prep course while 
attending first- or second-year of medical school. Only 2 (4\%) out of 50 first-year medical students stated they wished to take a prep course in the third-year of medical school. All other students would wish to take the prep course in fourth-year of medical school, as can be seen in Table 2, which contains the proportions among the students who responded positively to this question.

\begin{tabular}{|c|c|c|c|c|}
\hline \multicolumn{5}{|c|}{$\begin{array}{l}\text { In which grade do you intend to start a preparatory } \\
\text { course for the medical residency examination? }\end{array}$} \\
\hline & \multicolumn{4}{|c|}{ In which grade do you intend to start? } \\
\hline & $3^{\text {rd }}$ year & $4^{\text {th }}$ year & $5^{\text {th }}$ year & $6^{\text {th }}$ year \\
\hline $1^{\text {st }}$ year $(n=50)$ & $2(4 \%)$ & $5(10 \%)$ & $35(70 \%)$ & $8(16 \%)$ \\
\hline $2^{\text {nd }}$ year $(\mathrm{n}=54)$ & & $7(13 \%)$ & $37(68.6 \%)$ & $10(18.4 \%)$ \\
\hline $3^{\text {rd }}$ year $(n=30)$ & & & $25(83 \%)$ & $5(17 \%)$ \\
\hline $4^{\text {th }}$ year $(n=49)$ & & & $24(49 \%)$ & $25(51 \%)$ \\
\hline $5^{\text {th }}$ year $(n=10)$ & & & & $10(100 \%)$ \\
\hline
\end{tabular}

Regarding the reason why students do not intend to take a prep course to get ready for medical residency is the lack of money, although 27 (84.4\%) out of 32 students answered that, in fact, they consider the course necessary.

Thereafter, the following question was asked: what was the main motivation for you to take a prep course to get ready for medical residency examination? First- through fourth-year medical students pointed out three main reasons: 1) the need to learn the contents of medical residency examination; 2) review the content learned in the course, and 3) anxiety and insecurity to answer medical residency examination. Among fifth- and sixth-year medical students, the great majority pointed out that the only reason to take a prep course was the need to learn the content of medical residency examination

Regarding study material, structure, and fees of the main prep courses for medical residency examination, the overwhelming majority of all students who answered the question already had enough information or know these preparatory courses. Absolute numbers and percentages were as follows: $65 \%$ of first-year medical students, $80 \%$ of second-year medical students; $94 \%$ of third-year medical students; $98 \%$ of fourth-year medical students, and $100 \%$ of fifth- and sixthyear medical students.

The remaining questions were answered only by fourththrough sixth-year medical students. Figure 1 shows the number of preparatory courses known to students.

Next, students were asked about prep courses' fees this year. Figure 2 shows the answers.

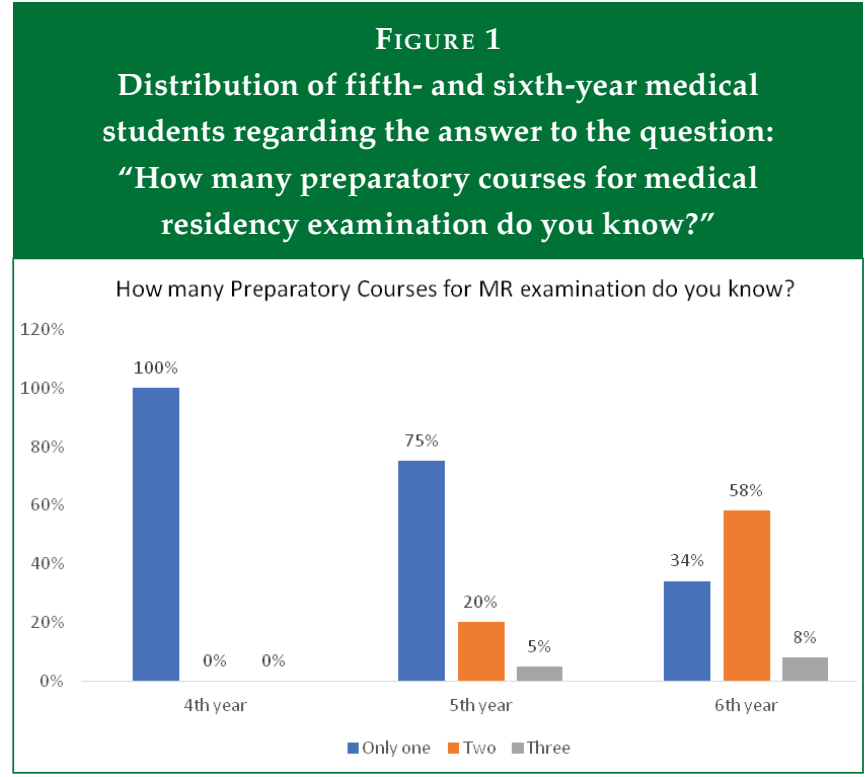

Figure 2

Distribution of fourth- to sixth-year medical students regarding the answer for the question: "What will be the amount spent to take the preparatory course this year?"

How much will it cost to complete the preparatory course this year?

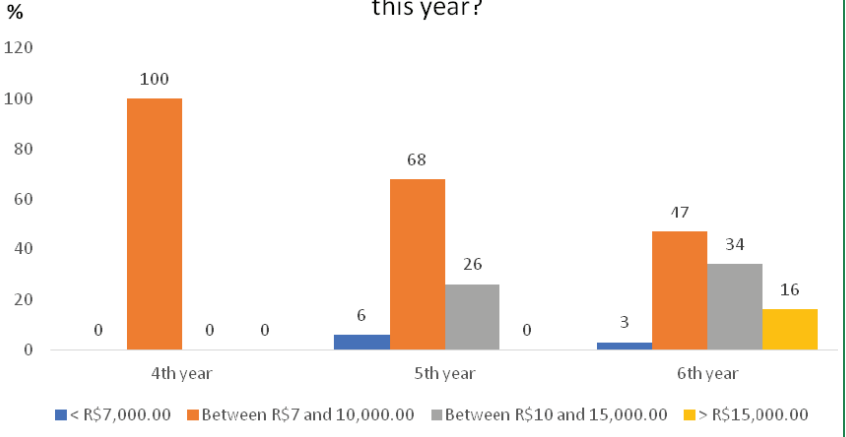

Amount of time dedicated to the classes and hours dedicated to the studies

Regarding the number of hours spent in classes of these prep courses, as well as to the hours dedicated to studies, it was observed that a minority (3.1\%) reported they spent less than 4 hours a week in class. The majority $(82.8 \%)$ reported they spent between 5 and 6 hours a week in class, and 14.1\% of the students reported they spent from 7 to 12 hours a week in class.

In relation to the hours per week dedicated to study (not counting class hours), fourth-year medical students reported they study more than 8 hours per week; Among fifth-year 
medical students who have finished the prep course, 33.3\% reported studying up to 4 hours per week; 33.3\% reported studying from 5 to 6 hours per week, and another 33.3\% reported studying more than 7 hours per week. On the other hand, among sixth-year medical students, 26\% reported studying up to 8 hours per week. However, $74 \%$ of them reported studying more than 8 hours per week.

\section{Vantage and disadvantage of the courses}

The highest quality of prep courses cited by fourth- to sixthyear medical students was the didactic approach. Table 3 demonstrates the results of this question.

\begin{tabular}{|c|c|c|c|}
\hline \multicolumn{4}{|c|}{ TABLE 3} \\
\hline & $4^{\text {th }}$ grade & $5^{\text {th }}$ grade & $6^{\text {th }}$ grade \\
\hline Classroom teaching & $1(100 \%)$ & $15(83 \%)$ & $24(52 \%)$ \\
\hline Study material & & $2(11 \%)$ & $16(35 \%)$ \\
\hline Content & & & $5(11 \%)$ \\
\hline All three & & $1(6 \%)$ & $1(2 \%)$ \\
\hline Total & 1 & 18 & 46 \\
\hline
\end{tabular}

On the other hand, when they were questioned about the greatest disadvantage of these prep courses, the great majority reported the dissociation of the concomitant theoretical and practical content experienced in clerkship. The results are shown in Table 4.

\begin{tabular}{|c|c|c|c|}
\hline \multicolumn{4}{|c|}{ TABLE 4} \\
\hline & $4^{\text {th }}$ year & $5^{\text {th }}$ year & $6^{\text {th }}$ year \\
\hline Study hours overload & & $1(5 \%)$ & $2(4.5 \%)$ \\
\hline Study content's overload & & $2(11 \%)$ & $2(4.5 \%)$ \\
\hline $\begin{array}{l}\text { Dissociation of theoretical and } \\
\text { practical content }\end{array}$ & $1(100 \%)$ & $12(67 \%)$ & $24(52 \%)$ \\
\hline Cost & & $3(17 \%)$ & $18(39 \%)$ \\
\hline Total & 1 & 18 & 46 \\
\hline
\end{tabular}

\section{Changes in medical education in order to avoid prep courses}

Finally, the students were asked what changes would be necessary to make these courses no longer an option to get ready for the medical residency examination. Table 5 shows the results when more than one option could be listed by the same student. On the other hand, Table 6 demonstrates the results when only one option could be chosen by the student. It was observed that the best didactic approach in undergraduate classes was the most chosen option, followed by an approach of theoretical content during internship.

\begin{tabular}{|c|c|c|c|}
\hline $\begin{array}{l}\text { TABLE } 5 \\
\text { What changes are needed to } \mathrm{m} \\
\text { courses no longer an option fo } \\
\text { residency examination prepa }\end{array}$ & $\begin{array}{l}\text { aake th } \\
\text { or med } \\
\text { aration }\end{array}$ & $\begin{array}{l}\text { lese } \\
\text { ical } \\
\text { ?* }\end{array}$ & \\
\hline & $\begin{array}{l}4^{\text {th }} \\
\text { grade }\end{array}$ & $\begin{array}{c}5^{\text {th }} \\
\text { grade }\end{array}$ & $\begin{array}{l}6^{\text {th }} \\
\text { grade }\end{array}$ \\
\hline $\begin{array}{l}\text { Best classroom teaching in undergraduate } \\
\text { classes }\end{array}$ & 1 & 15 & 35 \\
\hline $\begin{array}{l}\text { Approach of theoretical content during } \\
\text { clerkship }\end{array}$ & 1 & 10 & 30 \\
\hline $\begin{array}{l}\text { Medical residency examination emphasizing } \\
\text { practical/medical skills }\end{array}$ & 1 & 11 & 28 \\
\hline $\begin{array}{l}\text { More qualified teachers committed to } \\
\text { medical education }\end{array}$ & & 1 & 1 \\
\hline Task-oriented study at each stage & & 1 & 1 \\
\hline Improvement of evaluations & & 2 & \\
\hline $\begin{array}{l}\text { Hospital directed at the student and not the } \\
\text { resident }\end{array}$ & & & 2 \\
\hline $\begin{array}{l}\text { Do not have MR examination according } \\
\text { to the student's curriculum during } \\
\text { undergraduate course }\end{array}$ & & 1 & 1 \\
\hline Total answers & 3 & 40 & 121 \\
\hline
\end{tabular}

\section{TABLE 6}

What is the most important change to make

these courses no longer an option for medical residency examination preparation?*

$\begin{array}{ccc}4^{\text {th }} & 5^{\text {th }} & 6^{\text {th }} \\ \text { grade } & \text { grade } & \text { grade }\end{array}$

Best classroom teaching in undergraduate courses

$1 \quad 11 \quad 19$

Approach of theoretical content during clerkship

$3 \quad 10$

Medical residency examinations emphasizing practical skills

18

Medical residency examination emphasizing medical practice; Give preference to students coming from reference hospitals and not only to those who studied through books

MR examination consistent with the content applied during the undergraduate course

Undergraduate examinations that simulate MR

Expand the content to be taught and teach practical procedures, which the students did not learn at clerkship

End of the protectionism in all medical schools and reduction of competition/ vacancy

Total answers

$1 \quad 16 \quad 40$

* Only one option could be chosen. $M R=$ medical residency. 


\section{DISCUSSION}

In this study of the perception of medical residents and academics regarding prep courses for medical residency, fifthand sixth-year medical students declared they balanced the time allocated to clerkship activities and the study to take the examination, while 7 (24\%) of fifth-year medical students are dedicated to clerkship activities. Only 2 (4\%) of sixth-year medical students are dedicated to clerkship activities. Regarding the priority of the study to take the examination, 20 (37\%) sixth-year medical students said they have taken this attitude. Chehuen Neto et al. ${ }^{10}$ evaluated the expectations and opinions of seventh- to ninth-semester medical students, attending prep courses and found a progressive increase of students who adhere to the studies with the intention of passing the residency examination during their medical course ${ }^{10}$.

We observed in the final years of the medical school that more commitments were required from clerkship students because it is a decisive moment, in which practice and clinical experience are privileged. Regarding practical aspects, which are performed at bedside and in consulting rooms supervised by expertise physicians, the interns are more focused on studying theory at the expenses of compulsory clerkships in order to pass medical residency examination ${ }^{7}$.

In this study with 299 students, 297 stated the intention to become a physician resident. This result is supported by the study of Belarmino et al. ${ }^{11}$, with 255 students, in which $100 \%$ of medical students wanted to take a specialization course. Their first objective and option after completion of undergraduate degree were to follow medical residency ${ }^{11}$. In other words, the medical residency is seen by the vast majority as the only option after clerkship. However, Kubiak ${ }^{7}$ states that medical residency attends just over $40 \%$ of the demand, thus, half of undergraduate students or more will not have this opportunity ${ }^{7}$.

Ribeiro $^{12}$ makes it clear that the current Brazilian legislation does not require a Medical Residency Certificate to practice medicine. It is sufficient to have a valid medical degree issued by an institution accredited by the Brazilian Ministry of Education and registered in an equally accredited university and registered in the Federal Council of Medicine to have the right to the professional card and the national medical register. After that they are allowed to practice medicine ${ }^{12}$. Although the federal government does not require a mandatory Medical Residency Certificate, the professional who presents this certificate in labor market and in competitive examinations have a competitive leading edge in their curriculum, which produces an incongruity.

According to Leite et al. ${ }^{1}$ medical residency exams are a purely theoretical requirement that, besides discouraging the student for the development of the doctor-patient relationship, in the contact with prevalent diseases within the community and in the development of practical skills in university hospitals or colleges collaborates for the dissemination of prep courses for medical residency. However, Moraes ${ }^{13}$ points out that undergraduate course is no longer a competitive differential for a long time, and the market offers to those who did not have a post-graduate degree, few possibilities to progress within the profession and operational positions, as well as lower wages.

It is expected from the professional who finishes undergraduate education that he/she continues to improve his/her knowledge if he/she wants to keep pace with the evolution of the job market requirements, due to the demands on practical updates, resulting from the expansion and deepening of the theoretical background. In light of this context, the post-graduate program is part of the natural trajectory for professionals who want to achieve further career growth and pursue higher employability possibilities, besides enabling qualification and punctuation in public examinations, especially in the career of professor at higher education institutions. The requirements imposed by the social reality of every professional are to apply for further studies, such as a medical residency, as well as the permanent updating, not only as criteria for applying for a job at a university, but for everyone needing to enter the labor market $^{11}$.

It was observed that a large contingent of fifth- and sixthyear medical students, 55\% and 84\%, respectively, was taking a preparatory course for medical residency examination. Leite et al. ${ }^{1}$ also confirmed these statements, in a study reporting that the final year of undergraduate medical course is the period when most students intend to enroll in prep courses to medical residency examination.

The vast majority among the students said that they intended to take the course, and they would start it from fifthand sixth-year of college. In the study by Chehuen Neto et al. ${ }^{10}$, $76.03 \%$ of the interviewees also wish to apply to prep courses for medical residency examination, and $2.17 \%$ of ninth-year medical students were already enrolled in these courses ${ }^{9}$. In the study by Silva et al. ${ }^{2}$, it was found that $85.1 \%$ of the interviewees were already enrolled or wish to enroll in prep courses for medical residency examination. In the study by Silva et al. ${ }^{2}, 77.2 \%$ of clerkship students attended some type of prep course. The majority (57) were sixth-year medical students.

According to Silva et al. ${ }^{2}$, the insufficient number of places in medical area and in the most popular medical residency programs resulted in great concerns, insecurity, anguish, as well as in a rush among students attending the last years 
at medical school towards prep courses, which resulted in its proliferation.

In our study, 27 out of 32 students (84.4\%) claimed that, in fact, they considered prep courses necessary to get ready for medical residency examination. However, they alleged to have no financial resources to do so. Chehuen Neto et al. ${ }^{10}$ found that $63.17 \%$ of the students stated that they did not have financial conditions to pay for a prep course. Silva et al. ${ }^{2}$ found that $14.9 \%$ of those surveyed also stated they do not intend to attend prep course for residency due to their scarce financial conditions.

Due to high fees of prep courses, these courses became a new form of social exclusion in the dispute of places ${ }^{10}$. Leite et al. ${ }^{1}$ and Silva et al. ${ }^{2}$ pointed out that socioeconomic inequality can be decisive in the preparation of candidates. This means that those who benefit from the situation are those who have the best financial conditions and can pay for such prep courses.

With regard to the motivations to take prep courses, firstto fourth-year medical students pointed out three main reasons, as follows: learn the content covered in medical residency examinations, review the content learned in college, and the anxiety and insecurity to take medical residency examination. Silva et al. ${ }^{2}$ found that the main justification was also the possibility of carry out a content review or direct the studies: ten students $(17.5 \%)$ who participate or intend to participate in prep courses have as main justification fill out the gaps in classroom learning activities.

According to Kubiak ${ }^{7}$, undergraduate students with a faulty background and deprived of competence and skills are under constant publicity and media pressure, besides fear to fail medical residency examination. Starting from the thirdyear of college when a mental template of a well-drawn picture is outlined, and true vocational tendencies flourish, the students start living into a permanent state of anguish. This causes them to make important decisions precociously in the definition of his "specialty" and sometimes misleading ones".

Fifth- and sixth-year medical students pointed out as the main and only reason to take prep course, the need to learn the content covered by medical residency examinations. Thirty-six students $(53.7 \%)$ considered the participation in prep courses as crucial to their approval on the examination ${ }^{2}$. Silva et al. ${ }^{2}$ registered the interns' opinion and perception of the real function of prep courses in academic education. Students stated that prep courses expand medical knowledge and served only as training to get ready for medical residency examination. A significant part of students believes that prep courses fill out the gaps found in Higher-Education Institutions ${ }^{14}$.

The percentage of medical students aware of main information of prep courses, such as study material, structure, and fees is as follows: first-year (65\%); second-year (80\%); thirdyear (94\%); fourth-year (98\%), and fifth- and sixth-year medical students.

For Chehuen Neto et al. ${ }^{10}$, it is possible that almost all medical students, once in the faculty, are aware of the importance of residency examination and feel obliged to conform to this system ${ }^{9}$, once $100 \%$ of academics Interviewees were aware of this type of course. In addition to advertisement investments, prep courses are widely diffused due to their competence in approving students in medical residency programs, creating an expectation and instilling an idea of necessity.

As for the amount of class hours devoted to these courses, as well as hours dedicated to the studies, $82.8 \%$ of the students reported attending between 5 and 6 class hours per week, and $14.1 \%$ reported attending 7 to 12 class hours per week.

In relation to weekly hours dedicated to study (not counting class hours), fourth-year students said to study more than 8 hours per week. Among fifth-year students taking prep course, $33.3 \%$ reported studying up to 4 hours per week; $33.3 \%$ reported studying from 5 to 6 hours per week, and $33.3 \%$ reported studying over 7 hours per week. On the other hand, among sixth-year students, $26 \%$ reported studying up to 8 hours per week. However, $74 \%$ reported studying more than 8 hours per week.

Analyzing these data, it became clear the need of several hours of theoretical study as the medical residency examination approaches, which corresponds to substantial increase in study hours by sixth-year students, the last year of the undergraduate course. Focusing on hours of theoretical study at the expenses of dedicating to the clerkship impairs severely the academic background ${ }^{1}$. In the study of Silva et al. ${ }^{2}, 91 \%$ of respondents stated that the most important factor to be successful in residency examination is hours spent in theoretical study, which competes for a search to get a good professional training. When students dedicate themselves to theoretical studies, stressing the content addressed in medical residency examinations, the move further and further away from clinical activities of internship professional practice of the clerkship. This can cause skills and competences to be wasted, jeopardizing a full physician education ${ }^{8}$.

The highest quality of prep courses mentioned by fourthto sixth-year students was didactics in the classroom. Prep courses have an extensive infrastructure and a teaching structure, which are similar to the university entrance-exam preparatory courses. Learning material is quite objective and directed to solving test questions, with an attractive aesthetics, simple reading and discussion of previous test questions. These courses also present some facilities, such as intensive or exten- 
sive study modules, and live or distance learning. A teaching strategy used by these courses is to supply iPhones or notebooks to students, which is a strategic learning appeal due to many different possibilities ${ }^{8}$. On the other hand, $\mathrm{Kubiak}^{7}$ emphasizes that the courses adopt a pedagogical methodology that facilitates students to reach a greater number of correct questions in examinations. However, these courses are nothing more than a non-value-added tedious memorization of information, which is distanced from practice and clinical experience, distorting real learning of Medicine ${ }^{7}$.

Although the courses have a complete learning and teaching apparatus, this is not a guarantee of a better performance in medical residency examinations. The proof of this is that the study of Leite et al. ${ }^{1}$ showed there were no differences in approvals among students who attended prep courses or not. However, the performance of those who attended was better than that of those who did not: those who attended prep course obtained a weighted score of 4 points higher than those who did not attend prep courses, which does not represent a significant difference. In the study of Silva et al. ${ }^{14}$, it was verified that a higher percentage of interns (54.1\%), even when enrolled in prep courses, have failed to get noteworthy scores in the assessment test, which raises the question about the actual effectiveness of the prep courses regarding the acquisition of theoretical knowledge necessary to be approved in medical residency examinations.

However, with regard to the greatest disadvantage of these prep courses, the great majority mentioned the dissociation of theoretical and practical content addressed concurrently in internship. This demonstrates that students are fully aware of potential losses to their professional practice.

The importance of the practice experienced into clerkship is clearly demonstrated in the study of Silva et al. ${ }^{2}$, in which $95 \%$ of the participants stated that the activities carried out during clerkship are critical for their professional training.

Feitosa-Filho et al. ${ }^{15}$ reported that a well-trained physician would be more likely to make the right attitudes and safely. Under adequate supervision and intensive training, he/she will have a better chance to be well succeeded. A best professional qualification is likely to have an impact upon the job market, including a higher future wage.

Finally, students mentioned which changes would be necessary to make these courses no longer an option to get ready for medical residency examinations. Among the suggestions are a best didactics in undergraduate classes and a finest approach to theoretical content during clerkship. Students stressed deficiencies of both undergraduate course and clerkship program

\section{CONCLUSION}

We concluded that medical clerkship students and academics present a well-defined perception of prep courses for medical residency examination.

In spite of their adhesion to the practice of these courses, they are aware of the dichotomy between theory and practice, which is offered at the clerkship and this impairs vocational training. The great majority of students intend to follow medical residency after the clerkship, as the means to continuing their studies and their graduation studies. This position among the students perhaps is due to the great importance currently given to the title of specialist awarded by medical societies. This can only be achieved by taking a Lato Sensu Graduate course, in this case the medical residency.

In this study, students at the last year of clerkship privilege theoretical studies to the expenses of clerkship due to the emphasis on the medical residency examination, what justifies the title of the present work that reproduces a daily common situation of clerkship: where is the clerkship student who was here? On the other hand, the current situation in the labor market in the medicine field permeated by fierce competition, as well as the requirements of constant updating and improvement leads the students to see in the medical residency the natural path after clerkship and as an alternative to deal with clerkship possible deficiencies. There is a growing pressure in the last years of medical school that compels students to choose medical residency. It might be an early decision since there may be other alternatives. Changes in the undergraduate course reported by the respondents, such as the improvement of didactics in undergraduate classes and the theoretical content approach during clerkship, clearly reflect the deficiency of both undergraduate classes and clerkship program. Nevertheless, this can be solved with a more assertive attitude of teachers and preceptors.

\section{REFERENCES}

1. Leite ICG, Teixeira MTB, Neves HS, Oliveira LRS, Garcia LAO, Cunha PHM. Avaliação da Efetividade dos Cursos Preparatórios para Residência Médica. RBEM. 2008; 32(4): 445-451.

2. Silva SM, Rosa VF, Brandão PRDP, Oliveira ACD, Sousa, JBD, Oliveira PGD. Cursos preparatórios para a residência médica: visão dos estudantes de medicina. Rev. Col. Bras. Cir, 2011; 38(5): 349-354.

3. Almeida MJD. Ensino médico e o perfil do profissional de saúde para o século XXI. Interface-Comunicação, Saúde, Educação, 1999; 3(4): 123-132.

4. Brasil, Decreto no 80.281, de 5 de setembro de 1977. Regulamenta a Residência Médica, cria a Comissão Na- 
cional de Residência Médica e dá outras providências. [acesso em 12 maio 2017]. Disponível em: http://portal. mec.gov.br/index.php?option=com_content\&view =article\&id=13087\&Itemid=506.

5. Chaves L, Borges LB, Guimarães DC, Cavalcanti GLP. Vagas para residência médica no Brasil: Onde estão e o que é avaliado. RBEM, 2013; 37(4): 557-565.

6. Brasil, Lei no 6.932, de 7 de junho de 1981.Dispõe sobre as atividades do médico residente e dá outras providências [acesso 12 d e maio de 2017]. Disponível em: http: / /www. planalto.gov.br/ccivil_03/leis/L6932.htm

7. Kubiak CP. Não passei no concurso à residência médica, o que farei?Rev. Med. Res., Curitiba, 2013;15(3);188-192.

8. Hamamoto-Filho PT, Zeferino AMB. Cursinhos Preparatórios para Residência Médica: Reflexões sobre Possíveis Causas e Consequências. RBEM, 2011; 35(4): 550-6.

9. Alessio MM, Sousa MF. Regulação da formação de especialistas: inter-relações com o Programa Mais Médicos. Physis Revista de Saúde Coletiva, Rio de Janeiro, 2016; 26 [ 2 ]: 633-667.

10. Chehuen Neto JÁ, Sirimarco MT, Kawata Choi CM, Fava AS, Oliveira LRS, Cunha PHM. Cursinhos preparatórios para residência médica: expectativas e opiniões. RBEM, 2009;33(2):205-11.

11. Belarmino LM, MARTINS MF, FRANCO Mariane CA. Medical Aspirations: Analysis of Medical Students Boarding at Higher Education Institutions of Para. RBEM, 2016; 40(4):685-693

12. Ribeiro MAA. Apontamentos sobre residência médica no Brasil. Brasília (DF): Câmara dos Deputados-Consultoria Legislativa, 2011.

13. Moraes T. Pós-graduação é diferencial competitivo. Revista Ietec. 2010; 34:1-2.

14. Silva IR, Almeida LS, Gonsaga RAT, Biscegli TS (2012). Cursos preparatórios para residência médica: impacto do tempo de frequência no desempenho do graduando. CuidArte, Enferm. 2012; 6(1): 34-38.

15. Feitosa-Filho GS, Loureiro CMC, Almeida NR, Mascarenhas VN, Camurugy TC, Magalhães LB. Razões alegadas por médicos recém-formados em Salvador/BA em 2010 para não prestarem o concurso de residência médica. Rev Bras Clin Med. 2012; 10(2): 91-4.

\section{CONTRIBUIÇÃO DOS AUTORES}

This work was developed through a project of scientific initiation under the guidance of Professor Doctor Júlio César André. The undergraduate student of the Medicine course, Júlio César Razera de Melo was responsible for data collect and the analysis and interpretation of the data and for the final essay of the article it was made by Professor Doctor Patrícia da Silva Fucuta. Professor Doctor Alba Regina de Abreu Lima, Professor Master Science Sérgio Luíz Aparecido Brienze, and Professor Doctor Júlio César André were responsible for the design, data collection, final essay and critical review. The final version for English was performed by Professor Doctor Alexandre Lins Werneck.

\section{CONFLITO DE INTERESSES}

There is no conflict of interest.

\section{ENDEREÇO PARA CORRESPONDÊNCIA}

Júlio César André

Avenida Brigadeiro Faria Lima, 5416

Vila São Pedro - São José do Rio Preto / SP

CEP 15.090-000

E-mail: julio.andre@famerp.br 